\title{
A Western Folk Category in Mind?
}

\author{
HÅKAN RYDVING \\ University of Bergen
}

\begin{abstract}
Theoretically and methodologically, students of religion are groping in a borderland with a great variety of competing approaches. Most of these offer heuristic tools for the interpretation of those human activities that we group together with the help of the concept 'religion'. Others present religion as a 'real phenomenon' and offer explanations. The purpose of this article is to discuss some aspects of the most influential of the approaches in the second group, the 'cognitive science of religion'.
\end{abstract}

Keywords: cognitive science of religion, hermeneutics of suspicion, counterintuitivity, hypothesis testing

Can religion be explained, rather than merely analysed and understood in a fragmentary way? According to those researchers who enthusiastically subscribe to the 'cognitive science of religion'- a term that covers a heterogeneous group of loosely interrelated theoretical perspectives - the answer to this question is 'yes'. ${ }^{1}$ Launched as it was by several independent initiatives back in the 1980s and 1990s (Guthrie 1980; Lawson \& McCauley 1990; Guthrie 1993; Boyer 1994), various cognitive approaches to religion have seen impressive development over the past few years: several research centres, projects and research groups have been initiated ${ }^{2}$ and a journal

\footnotetext{
${ }^{1}$ Cf. the overviews in Lawson 2000, Martin 2005, and Sørensen 2005, which focus on the theories of Boyer, Whitehouse and Lawson \& McCauley. Bulbulia 2004 also covers so-called adaptionist theories, which regard religion as a product of evolution, and Geertz 2004 presents a large number of cognitive approaches to religion.

${ }^{2}$ In addition to the project Religion, Cognition and Culture (University of Aarhus), the Institute of Cognition and Culture (Queen's University, Belfast), the Centre for Anthropology and Mind (University of Oxford), and the Culture and Cognition Program (University of Michigan) all focus to a large extent on religion.
} 
and a monographs series launched ${ }^{3}$ - not to mention the many articles and books published by cognitivists of religion in other journals and with other publishers, and the many seminars and panel discussions at conferences that have dealt with various aspects of the theme 'religion and cognition'. Despite all this activity, the cognitivists' influence on the general academic study of religion has been limited. While the cognitivists debate among themselves, viewing their perspectives as invaluable theoretical contributions to the study of religion and adopting a highly critical stance towards other approaches, they tend to be either criticised in return or ignored by the majority of students of religion. ${ }^{4}$

Why are cognitive approaches - like no other current theoretical perspective relating to the areas of culture we label 'religious' - embraced with such uncritical and panegyric devotion by some, while being rejected with such hypercritical comments and even condemnation by others? In this case, there seems to be no borderland where a critical and open-minded debate about the prospects and limitations of the approach can take place. Why is there such a clear-cut division between cognitivists and the rest, between the 'converted' and the 'non-believer' in this new approach?

These questions form the starting point for the following discussion. I intend to answer them by identifying a series of problems, which in my view may at least partly explain why students of religion who - like myself - draw their theoretical inspiration from other sources are so hesitant about the cognitive science of religion.

It is important to emphasise that what I am going to discuss is not the obvious fact that cognition is essential to everything we think and do as human beings, ${ }^{5}$ including those aspects of culture we demarcate from other aspects of culture by means of the term 'religion', but rather the ways in which the relation between cognition and religion is perceived, analysed and explained within 'the cognitive science of religion', as formulated - albeit in different (in some cases even mutually exclusive) ways - by such researchers as Scott Atran, Justin Barrett, Pascal Boyer, Joseph Bulbulia, Stewart Guthrie, Thomas Lawson, Robert McCauley, Ilkka Pyysiänen, D. Jason Slone, and

\footnotetext{
${ }^{3}$ The range of ambition of the Journal of Cognition and Culture published by Brill is wider than just religion, in contrast to the Cognitive Science of Religion Series published by AltaMira Press.

${ }^{4}$ I owe many thanks to Steven Sutcliffe (Edinburgh) for his response. Peter Cripps (Berlin) and Ellen Valle (Turku) have helped me to improve not only my English but the logic of the text as well.

${ }^{5}$ Cf. Flood 1999, 62 f.
} 
Harvey Whitehouse. ${ }^{6}$ Although my comments are critical, I would like to stress that they are offered from a position of curiosity and interest. I find these approaches theoretically interesting and therefore worthy of serious debate. If I regarded them as uninteresting, I would not be devoting time to discussing them.

Needless to say, my comments do not arise from within a vacuum, but spring from a standpoint informed by a hermeneutics of suspicion. This means that when reading and re-reading texts belonging to the growing corpus of the cognitive science of religion, I have focused on contradictions, inconsistencies and gaps between ideal and practice: between on the one hand what is said in the introduction and conclusion of a text, on the other its empirical substance (tests, experiments etc). In particular, I have been suspicious of the claim that the cognitive science of religion can be included among the natural sciences.

Before moving on to my comments, I need to say something about terminology. To take the word 'natural' first: it is a word used by cognitivist students of religion in two different senses, as the opposite of 'unnatural' and as the opposite of 'cultural', and it is not always clear which meaning is intended. When used in the first sense, 'natural' simply means that religious beliefs and practices are regarded as natural in the sense that they 'enlist ordinary cognitive resources' (Barrett \& Nyhof 2006, 169). ${ }^{7}$ For sceptical outsiders it is hard to grasp the heuristic importance of this often repeated argument, since it seems self-evident. ${ }^{8}$ When used in the second sense ('natural' as the contrary of 'cultural') in connection with religion, 'natural' implies among other things that religion is amenable to analysis using methods from the natural sciences. Although some branches of the

\footnotetext{
${ }^{6}$ In writings such as Atran 2002; Barrett 2004b; Boyer 1994, 2001; Bulbulia 2004, 2005; Guthrie 1980, 1993; Lawson 2000, 2004; Lawson \& McCauley 1990; McCauley \& Lawson 2002; Pyysiäinen 2001, 2004; Slone 2004; Whitehouse 2000, 2004. All of these researchers, except for Bulbulia, represent various versions of the so-called non-adaptionist stance of the cognitive science of religion. This imbalance in the selected readings is due to the fact that non-adaptionists (religion is a by-product of evolution, without adaptive functions) have so far been more influential in the comparative study of religions than adaptionists (religion is a product of evolution, an adaptation to the environment). Cf. the articles in Andresen 2001; Gothóni 2005, $59 \mathrm{ff}$. (with critical comments); Pyysiäinen \& Anttonen 2002; Whitehouse \& Martin 2004; Whitehouse \& McCauley 2005.

7 Cf. Boyer 1994; Barrett 2006, 2004a.

${ }^{8}$ Does it mean that there is also (according to cognitivist scientists of religion) some 'unnatural' or 'non-ordinary' type of cognitive resources that could be used instead? Or, is this argument (although this is not explicitly stated) aimed at theologians rather than other non-theological students of religion?
} 
cognitive science of religion try to relate what are regarded as the natural and the cultural aspects of religion to one another (Jensen 2002), the main focus is still on the natural.

Secondly, the verb 'explain' and the derived noun 'explanation' are even more important to the way cognitive students of religion see themselves as scientists rather than scholars, in that the main difference between the research methods and theoretical approaches of the sciences on the one hand and the humanities on the other is often expressed in terms of the simplistic dichotomy of 'explanation' and 'understanding'. .9 Since the cognitive science of religion claims emphatically to be a natural science, its explanations should be of the same type as those in the natural sciences. Among other things this means that they have to be based on hypotheses that have been broken down into testable elements and tested in well-designed experiments. However, since the cognitive science of religion has focused more on formulating hypotheses than on testing them, ${ }^{10}$ and has not always lived up to the strict demands of hypothesis testing in science, this is a problematic claim.

Thirdly, it should be noted that I use the words 'student' and 'study' (as in 'students of religion' and 'the study of religions'), or sometimes 'researcher' and 'research', in order to avoid having to choose between scholar/scholarship on the one hand and scientist/science on the other. I will only make this distinction when it is important to my argument.

Fourthly, in this article I use the term 'cognitivists' in the restricted sense of students of religion working within 'the cognitive science of religion', not for other cognitivist researchers, most of whom refrain from regarding 'religion' as a mind-dependent universal entity. ${ }^{11}$ On the other hand, several cognitive approaches other than the rather narrow one that refers to itself as 'the cognitive science of religion' have been used in the analysis of 'religion', such as those inspired by George Lakoff and Mark Johnson

\footnotetext{
${ }^{9}$ Cf. von Wright 1993; Manicas 2006, $7 \mathrm{ff}$. For discussions of possible relations between explanation, interpretation and description see Lawson \& McCauley 1990, 12 ff; Jensen 2003, $223 \mathrm{ff}$.

${ }^{10}$ A point to which some 'insiders' have also drawn attention. Whitehouse $(2002,149)$, for example, has indicated that cognitive students of religion 'need to be pursuing further empirically verifiable claims, and not simply promulgating ever more extravagant metaphors in the name of critical originality', while according to Barrett (2004a, 415) 'the cognitive science of religion has many claims as yet insufficiently supported by rigorous empirical data' (cf. Barrett 2006, 95).

${ }^{11}$ It is no surprise that introductory textbooks in cognitive psychology - such as Ashcraft 2006, Kolak et al. 2006, and Reisberg 2006 - list 'religion' as a topic neither in their tables of content nor in their indices. This also applies to manuals in cognitive anthropology, such as Cerulo 2002, or Kövecses 2006. Cf. Alles 2006, 325.
} 
that are discussed in Kim Knott's article in this volume. An important difference compared to researchers within the cognitive science of religion is that Lakoff and Johnson (1980; Lakoff 1987) do not present their perspective as an approach to analysing 'religion'. ${ }^{12}$

Fifthly, it is important to note that the term 'cognitive science of religion' in the singular might give the wrong impression that this field of study is uniform, whereas it is in fact highly diverse and heterogeneous. Nevertheless, I retain this term, since it is the one preferred by those inside the field.

\section{The Problem of Style}

All too often - whether in reviews or in texts discussing theoretical themes - it seems to be a rule to use irony and arrogance in discussing the perspectives of others. The study of religion is in this respect no exception; in recent decades, a few students of religion have even been able to build reputations on little more than their hostility and their hyper-critical attitude towards the writings of others. Unfortunately, some cognitivists of religion tend to display this negative attitude towards all those who do not use a cognitive perspective, something which conceals the fact that there exists a multiplicity of non-theological approaches to religion other than the cognitive; approaches that - like cognitive ones - emphasise that the study of religion requires no privileged approach or method but rather is the study of ordinary human activities of attribution' ${ }^{13}$

\section{The Problem with Hegemonic Claims}

If the confrontational style sometimes makes it difficult to remain neutral and focused on the logic of the argumentation when reading texts inspired by the cognitive science of religion, the same is true of the hegemonic claims sometimes expressed in these writings. These claims have to do, at least in part, with how theories are perceived - whether as more or less absolute or as heuristic tools; and there is no doubt that cognitivists of religion regard

\footnotetext{
12 It should be noted that in the central books by the founding fathers of the cognitive science of religion, the works Lakoff \& Johnson 1980 and Lakoff 1987 are, strangely enough, discussed only in Lawson \& McCauley 1990, but not in Guthrie 1993, Boyer 2001, Pyysiäinen 2001, Barrett 2004b, or Whitehouse 2004.

13 To quote Martin's $(2005,483)$ characterisation of an approach he seems to attribute solely to the cognitive science of religion. Sørensen $(2005,468)$ also seems to think that to study religion by 'methods used to study non-religious phenomena' (italicised in the original) is something that the cognitive science of religion has introduced into the study of religion.
} 
theories (especially their own) as far more absolute than other students of religion do. But when cognitivist researchers claim that their way of studying religion is the only possible or legitimate or scientific one ${ }^{14}$ they are moving into highly problematic territory.

Although it is possible to understand the enthusiasm of colleagues who have searched in many directions for theoretical tools to help them with their research questions, and have finally found them in the cognitive science of religion, ${ }^{15}$ this hegemonic ambition of some of its advocates has to be rejected. Among the many approaches to 'religion', there is certainly room for cognitive ones; yet they cannot be our only tools. If they were, we would be able to analyse only some of the ritual, narrative, ethical, genderrelated, social and other aspects of those phenomena we call religious, but not others.

\section{Some Epistemological, Theoretical and Methodical Problems}

If it were not for the confrontational style and hegemonic ambitions just mentioned, students of religion interested in aspects of their subject other than cognitive ones would, I think, be much less negative towards the cognitive science of religion. That said, we can put this theme aside, since it is independent of the far more important epistemological, theoretical and methodical problems that will be in focus henceforth.

\section{The Problem with the Unsettled Epistemological Status of 'Religion'}

To make a claim that may seem bolder than it actually is: from one point of view, the cognitive science of religion can be regarded as a new discourse about religion as something sui generis, as an entity of its own kind. In contrast to the old and abandoned paradigm, which was informed by philosophical realism and which regarded religion as a mind-independent universal entity, the cognitive sui generis discourse about religion is informed by philosophical conceptualism; with the consequence that religion is presented as a mind-dependent universal entity, even if that entity is no more than a by-product of the evolution of the brain.

However, there is ambivalence in the ways religion is represented within the cognitive science of religion, and this ambivalence can be attributed in

\footnotetext{
${ }^{14}$ Cf. for example Martin 2005, 485. Other representatives of the cognitive science of religion seem to accept interpretative approaches along with explanatory ones. See for example Lawson \& McCauley 1990, 12 ff.; Sørensen 2005, 467.

${ }^{15}$ Cf. the detailed 'conversion story' in Pyysiäinen 2004, xiii ff.
} 
particular to the fact that the epistemological status of 'religion' has not been clarified. On the one hand, one finds writings with such titles as Religion in Mind or Religion Explained, ${ }^{16}$ which talk about religion as if it were an entity of some kind, 'a real although somewhat vague phenomenon', to quote Pyysiäinen (2002, 111); on the other, at least some cognitivists of religion also maintain that 'religion', in accordance with the general understanding of the word, is 'a heuristic device, used by scholars to lump together phenomena that seem to have some kind of family-resemblance' (Pyysiäinen 2001, 1). ${ }^{17}$ It seems as though cognitivists who discuss religion speak with two voices. On the one hand they want to explain those aspects of human culture we call religious, and in order to do so 'religion' has to be something more than a concept; on the other they are aware of the fact that religion is a local folk category used as a concept. However, if this aspect were emphasised there would be nothing to explain and the whole enterprise would be futile. ${ }^{18}$ This probably explains why cognitivists of religion tend to avoid serious discussion of writings by critical scholars who analyse the concept of religion and the extent of its applicability. ${ }^{19}$

\section{The Problem with Pars Pro Toto Arguments}

Another typical aspect of the cognitive science of religion is its minimalist understanding of religion, ${ }^{20}$ or, more accurately, the tendency to focus on and analyse some small element of what is usually regarded as the religious complex, as if it represented the totality: whether that subset is the alleged counterintuitivity of certain beliefs (Boyer and Pyysiäinen), their intuitivity and anthropomorphisms (Guthrie), the importance of culturally postulated superhuman agents in religious systems (Lawson \& McCauley), two modes of religiosity related to two types of memory (Whitehouse), intuitive theism (Bulbulia), or something else.

Most students of religion seem to agree that the field of investigation demarcated by the analytical concept 'religion' is, if nothing else, characterised by complexity and variation. In order to capture this multiplicity, some researchers have talked about aspects or dimensions of religion. Thus

\footnotetext{
16 Andresen 2001; Sørensen 2005; Boyer 2001.

17 Cf. Boyer 2001, $329 \mathrm{f}$.

18 What Lévi-Strauss $(1996,18)$ once wrote about 'totemism' is, I think, equally valid about 'religion': that it is 'une unité artificielle, qui existe seulement dans la pensée de l'ethnologue, et à quoi rien de spécifique ne correspond au dehors'.

19 I am thinking of books like Smith 1982, Asad 1993, Balagangadhara 1994, Dubuisson 1998, Fitzgerald 2000, McCutcheon 2003, and Masuzawa 2005.

${ }^{20}$ For the term 'minimalistic' see Lincoln 2003, $58 \mathrm{ff}$.
} 
- to take examples from three very different students of the subject - Ninian Smart $(1983,15 \mathrm{ff}$.) proposed his often repeated list of the ritual, mythological, doctrinal, ethical, social, and experiential dimensions; Meredith McGuire (1992, 15 ff.) speaks of belief, ritual, experience and community aspects; while Bruce Lincoln (2003, 5 ff.) defines religion in terms of a discourse, a set of practices, a community and an institution. The cognitive aspects represent only one part of this totality, aspects which non-Protestant students of religion have characterised as typical of a Protestant Christian approach that views religion as primarily a matter of 'belief'. ${ }^{21}$

This means that when advocates of the cognitive science of religion present 'religion' as 'explained', in reality they have only been addressing some part (a subset) of one aspect or dimension of the complex totality that we use the concept of religion to demarcate. Where some subset of conceptual strategies has been analysed, this finding should be presented as an explanation of that subset, which it is, and not as an explanation of a totality ('religion'), which it is not.

\section{The Problem with 'Counterintuitivity'}

One of the problematic sub-categories used within some branches of the cognitive science of religion is 'counterintuitivity'. This term was introduced by Pascal Boyer $(1994,2001)$ and developed by Ilkka Pyysiänen $(2001,2002)$, and it has become one of the most important as well as one of the most contested technical terms in the cognitive science of religion. First of all, it is worth noting that the whole idea that counterintuitivity is the 'hallmark of religiosity', or the 'bedrock of religion' ${ }^{22}$ - as Pyysiäinen has claimed it to be - has also been contested within the cognitive science of religion: most explicitly by Stewart Guthrie (2002, $41 \mathrm{ff}$.), according to whom religious concepts are on the contrary quite intuitive and based on anthropomorphisms, but also by others, for example by Joseph Bulbulia (2004, 2005), who regards children as intuitive theists. ${ }^{23}$ Another consideration is that this hypothesis does not distinguish between on the one hand for example fictional figures, such as Pikachu ${ }^{24}$ or Harry Potter, on the other 'culturally

\footnotetext{
${ }^{21}$ This Protestant turn in the cognitive science of religion is not always as clear as in Barrett $2004 \mathrm{~b}$, where not only the title but all the chapter headings include at least one of the words 'belief(s)', 'believe' or 'believing'.

22 Pyysiäinen \& Lindeman \& Honkela 2003; Pyysiäinen 2002, 121.

${ }^{23}$ The discussion within the cognitive science of religion about counterintuitivity vs. intuitivity is of the utmost importance, but if the empirical tests that are regarded as supporting the hypothesis of counterintuitivity were well executed, there must be something wrong with those regarded as supporting intuitivity, and vice versa.

24 The best-known of the Pokémon figures.
} 
postulated superhuman agents' (to use the term preferred by Lawson \& McCauley), such as Vishnu or Isis. ${ }^{25}$

For my own part I would offer a critique from another angle, which can be summed up by the question: 'Counterintuitive for whom?' Religious representations might perhaps be viewed as informed by (minimal) counterintuitivity by secular, post-Enlightenment westerners such as ourselves, but that does not mean that it can be taken for granted that counterintuitivity is regarded as a characteristic trait of religion among humans (or religious people) in general. In any case, if that is the hypothesis, it has to be subjected to cross-cultural testing in well-designed experiments, but to my knowledge this has not yet been done. Some empirical evidence for the hypothesis has to be sure been presented (see below), but it has been cross-cultural only to a limited degree, and the tests have not met the requirements of hypothesis testing within the natural sciences.

\section{The Problem with the Analogy Between Religion and Language}

It is not uncommon, at least within some branches of the cognitive science of religion, to draw an analogy between religion and language (cf. Lawson \& McCauley 1990; Lawson 2000; Bulbulia 2005).

Linguistic cognitivists seem to agree that language is a cognitive capacity that developed in the course of the evolution of the brain, whereas cognitivists who deal with religion discuss among themselves whether religion is a product or a by-product of evolution. ${ }^{26}$ The majority seems to go for the second option, which can be reformulated as follows: 'certain cognitive capacities that we in the West deal with under the heading of religion are evolutionary by-products'. This would mean that even from a strictly cognitive point of view language and religion are not commensurable phenomena - something that makes it hard to understand why this analogy is used at all by those who adhere to the by-product hypothesis.

The problematic character of the analogy between religion and language (disregarding the evolutionary status attributed to religion) becomes clear if

\footnotetext{
${ }^{25}$ See Pyysiäinen 2002, $114 \mathrm{ff}$. and Sørensen 2005, $473 \mathrm{ff}$. for brief summaries of the discussion about 'the Mickey Mouse problem' etc. i.e., the fact that not only 'religious representations' but also fiction, mental disturbance and even science are counterintuitive. To me, this fact (which is noted by cognitivists of religion) makes it hard to understand how empirical tests of hypotheses about counterintuitivity can be regarded as tests of religious representations (see below).

${ }^{26}$ Cf. the overview in Bulbulia 2004. Sjöblom (2007) has recently suggested a combination of these two stances.
} 
we compare situations where the phenomena are inoperative. It is possible to choose to be religious or not, but it is not possible to try to live without language. To have lost one's linguistic capacities and become aphasic is regarded as a severe mental disturbance; to lose one's religion and become an atheist is not regarded as an illness, -quite the opposite. To be without language makes it very difficult to function as a human being and is regarded as unnatural, but to be non-religious or an atheist does not mean that one is regarded as less human or as unnatural in any way, and does not render life more difficult, except of course in intolerant religious environments. Simply stated: since atheism is not analogous to aphasia, religion cannot be analogous to language.

\section{The Problem of Insufficient Cross-cultural Empirical Evidence}

When one reads writings by cognitivist students of religion, one is surprised by the important role played by qualitative arguments. ${ }^{27}$ For a field of study that claims to belong to the natural sciences, one would imagine that this type of argument, typical as it is of the humanities and the social sciences, would be avoided. Quite often, however, long lists of examples from various cultural contexts are used to support the hypothesis in question, whereas empirical evidence, in the sense in which the term is used in the natural sciences, is much less common. In addition, the lists tend to consist almost exclusively of examples that support the hypothesis; there are few if any examples that contradict it, and there is little evaluation of arguments in favour of or against the hypothesis, or of its level of probability. Rather, it seems to be taken for granted..$^{28}$

There are, it is true, examples of cognitive hypotheses of religion that have been tested by means of questionnaires or interviews, but in most cases the test subjects have a cultural background very similar to that of the researcher. ${ }^{29}$ I will comment briefly on some well-known 'empirical tests'. Except for the first of them, all have been (re)published in a reader edited by D. Jason Slone, author of one of the key works in this field of research

\footnotetext{
${ }^{27}$ As, for example, in Boyer 2001, Pyysiäinen 2004, Barrett 2004b, to mention three of the most influential monographs.

${ }^{28}$ As when Barrett (2006) concludes one of his articles with the expectation that 'further experimental and ethnographic work will provide rigorous empirical data to support the claims of this new science of religion' (emphasis added), not (as one would have expected) 'provide rigorous empirical data' that would make it possible to test the hypotheses.

${ }^{29}$ Despite the fact that 'cross-cultural replications are indispensable' (Boyer 2001, 83).
} 
(Slone 2004). This background makes it reasonable to regard these tests as representative. $^{30}$

(1) In an article where we are presented with what is called 'empirical evidence for the hypothesis that persons consider counterintuitive representations more likely to be religious than other kinds of beliefs' (Pyysiäinen et al. $2003,341)$, the test groups consisted of undergraduate and graduate students from Finland, Ireland, the USA and France, i.e., individuals with the same type of western education. At best, then, the results might tell us something about how at least some European and American university students consider counterintuitive representations, but that is certainly not the same as saying that human beings or people in general would do the same. The results cannot be used to support a hypothesis about the human mind.

(2) In the majority of the tests that Slone presents in his reader the cultural background of the participants is even more limited, consisting at most of persons from various parts of the United States. For example Barrett and Keil's (2006) investigation of anthropomorphism in God concepts involved 52 graduate and undergraduate university students in one study and 81 college students in another. All of them were probably North American, but the authors do not give any information about cultural background. On the other hand, they do supply information about religious affiliation, age and gender.

(3) Barrett and Nyhof's (2006) study of the role of intuitive conceptual structures in memory and transmission in culture involved 48 American university students in one experiment and 54, 23 and 27 American college students respectively in three other experiments.

(4) Barrett and Lawson's (2006) article on cognitive contributions to judgments of ritual efficacy is based on experiments with 128 North American Protestant college students.

(5) Evans' (2006) informants were 102 'Christian fundamentalist children' and 83 'non-fundamentalist children' and their parents ('one father; the rest, mothers and female guardians') from '26 rural and suburban towns and cities' (p. 240) in the midwestern United States.

(6) Bering and Bjorklund (2006) interviewed a total of 199 children from

\footnotetext{
${ }^{30}$ I have chosen Pyysiäinen et al. 2003 plus the eight articles with 'empirical evidence' that are (re)published in Slone 2006a as a representative sample: Barrett \& Keil (1996) 2006; Barrett \& Nyhof (2001) 2006; Boyer \& Ramble (2001) 2006; Barrett \& Lawson (2001) 2006; Evans (2001) 2006; Knight et al. (2004) 2006; Bering \& Bjorklund (2004) 2006 and Richert 2006.
} 
two university-affiliated schools in a suburban metropolitan area of south Florida for their investigation into the natural emergence of reasoning about afterlife.

(7) Richert (2006) gives no information about the cultural background (presumably North American), age or gender of the participants in her two experiments testing the role of analogical reasoning in modes of religiosity.

(8) Only one of the empirical studies in Slone's reader can be regarded as cross-cultural. Boyer and Ramble (2006) based their investigation of counter-intuitive representations on experiments conducted with a total of 61 university students from Lyon in France, 81 persons (with French as their first language) who were 'recruited informally at Libreville farmers' markets' (p. 196) in Gabon, and 30 Tibetan monks (all native speakers of Tibetan) from a monastery in Kathmandu (Nepal). While the authors interpret the results of these experiments as supporting their hypothesis, they are well aware of certain methodological problems that render the interpretation of the test results difficult: the similarities between the French and the Gabonese groups could, they admit, be a result of the fact that they 'were both taken from populations with minimal exposure to scholarly, literate religion' ( $p$. 199), while the differences between the French group and on the one hand the Gabonese group, on the other the Tibetan one might be 'explained by the special cultural context' (p. 203). The fact that these two problems make the test results difficult to interpret and may even compromise the value of the whole experiment is, however, not discussed. ${ }^{31}$

(9) The study by Knight et al. (2006) was based on interviews (in the local Yukatek Maya language) with 48 Maya children from the Yucatan peninsula in Mexico. This means that the empirical study is not cross-cultural as such; however, since the results are compared with the results of a similar investigation carried out in the United States this comparison is cross-cultural. As a critical reader one notes that the different test results found for children from the United States and Mexico did not lead the authors to question either the hypothesis or the test design. Instead, they prefer to explain the differences with reference to the fact that the Maya children were less familiar with the question/response format, and to the small sample size (p. 294).

Quite often, different hypotheses within the cognitive science of religion are supported by references to the two last-mentioned tests. The problems and provisos discussed in the original articles, however, are passed over in

\footnotetext{
31 This study is the one most often referred to when cognitive scientists of religion want to emphasise that their field of research is based on cross-cultural empirical evidence.
} 
silence. Instead, the mantra of the cross-cultural proofs of the hypotheses is repeated. ${ }^{32}$

\section{The Problem of Inadequate Hypothesis Testing}

Another problem with the empirical evidence for various cognitive hypotheses about religion is that it does not live up to the strict demands of hypothesis testing in the natural sciences. The most important of these demands is that in testing a hypothesis one has to try to find arguments not only in its favour but also against it. Secondly, the research questions must be sufficiently specific and operationalised so as to be testable. As far as I have seen in writings by cognitive students of religion, neither of these two demands on research experiments is met and there are many problems with the design of the tests. I hope to be able to discuss some of these problems at length in another paper. Suffice it to note in this connection that there is not always a clear relation between the (rather limited) tests and the (sometimes very general) conclusions drawn. Some examples:

(1) When Barrett and Keil (2006) report their test results, which in their view show that their subjects used an anthropomorphic concept of God that 'is not the same as the concept of God that is claimed in a more abstract, theological setting' (p. 138), their idea of theological 'God' concepts is based merely on their own assumed theology; they did not conduct any tests to find out what theological ideas of 'God' were already held by the subjects or the religious groups to which they belonged. Since Barrett and Keil therefore knew nothing about the 'theological concept' of 'God' among the subjects participating in their tests, their conclusions - that the God concepts offered by the subjects were 'not independent of [his or her] personal theology' (p. 139), and that 'it seems important when making claims about God concepts to differentiate between the theological concept and the concept used in everyday life' ( $\mathrm{p}$. 142) - are unfounded (which is not to say they are not plausible, but that is another matter). ${ }^{33}$ The conclusion as to the relation between two different God concepts is even more problematic, since '[m]any subjects reported being

\footnotetext{
32 For instance, when Slone (2006b, 7) introduces the article that compares interviews with a group of Maya children in Mexico with a similar investigation in the United States (Knight et al. 2006), he maintains that the article shows 'that children across cultures reason' (emphasis added) in certain ways about gods' minds, a clear overstatement of the test results.

33 The conclusion is repeated by Boyer $(2002,80)$, who calls this article a 'detailed experimental work' and claims (as do the authors) that it shows 'that people's explicit notions of an omniscient God are combined with an intuitive understanding of God as having a human-like mind', in spite of the fact that this hypothesis was never tested.
} 
atheist or agnostic' (p. 122), i.e. did not have a theological agenda at all.

(2) Barrett and Nyhof (2006) discuss non-natural concepts which in their view provide support for 'Boyer's theory that counterintuitive concepts have transmission advantages that account for the commonness and ease of communicating many non-natural cultural concepts' (p. 167). However, none of the tests presented deal with 'religious' concepts, although this does not prevent the authors from drawing conclusions about religious concepts from them (p. 169 f.).

(3) Boyer and Ramble's (2006) famous cross-cultural experiments investigated religious-like (not religious) counterintuitive representations; this ought to rule out the possibility of drawing any conclusions about 'religion' from these tests, even if that was the intention. What was in fact concluded from the tests was (1) (France) that 'sentences that include a breach of expectations are recalled better than standard ones' (p. 187); (2) (France) that 'items including a transfer of predicates from another category would be better recalled than items without such transfer' (p. 190); (3) (France) that 'properties that are intrinsically counterintuitive are recalled better if they are appropriate for the category, less if they are not' (p. 194); (4) (Gabon) that 'violations of domain-level information trigger high recall for both artefact and person concepts' (p. 199); and (5) (Nepal) that 'items including domain-level violations are generally recalled better than common conceptual associations, while violations of kind-level information do not produce such effects' (p. 202 f.). Despite the fact that the representations investigated were not religious but religious-like, in the general discussion (p. $203 \mathrm{ff}$.) the authors present the tests as if they had tested religious representations. The fact that certain non-religious items were remembered better if they violated domain-level information than if they did not cannot be used to conclude anything about 'religious representations', as no such representations were tested. Since not all counterintuitive representations (even according to Boyer) are religious, and, therefore 'counterintuitiveness is not a sufficient criterion for religion' (Pyysiäinen 2002, 115), tests of counterintuitive representations, such as those in the study by Boyer and Ramble, cannot be used to either falsify or support any hypothesis about 'religion'. ${ }^{34}$

(4) When Pyysiäinen et al. (2003) tested whether persons 'in fact regard counterintuitiveness in general as a marker of religion' (p. 344), they inter-

\footnotetext{
${ }^{34}$ Cf. Pyysiäinen 2001, 2: 'A general theory of religion would require that there actually exists a separate class of religious phenomena that can be explained by a set of distinct laws. This is not the case if religious representations are actually produced by cognitive mechanisms that also produce non-religious representations.'
} 
preted the results as showing that the 'subjects judged the counterintuitive representations to be more likely religious [...] than the intuitive ones' (p. 345 ; cf. p. 347, 352). But the subjects were only 'asked to rate how likely each of the beliefs and events described in the statements was to be religious' ( $\mathrm{p}$. 345). This means that other possibilities of counterintuitive domains, such as fiction, mental disturbance and scientific representations (cf. Pyysiäinen 2002, $114 \mathrm{f}$.), were not tested. The results of the test thus do not support the hypothesis, since it was never adequately tested. When in addition the authors draw the general conclusion from their tests that '[a]ll that is needed to activate a religious interpretation is ontological violations', following this up with the assertion that ' $\mathrm{t}$ ] his finding in turn suggests that there may be a common core to all religiosity' (p. 353; emphasis added), a critical reader cannot help wondering how such a far-reaching conclusion could be drawn from the limited empirical material.

To characterise the results of these studies as 'experimental findings that provide robust support for core hypotheses in the field', as Slone (2006b, 9f.; my emphasis) does, is to overstate the rather meagre empirical evidence under consideration. It is difficult to understand how it is possible to draw any conclusions about 'religion' or the human mind or cognition in general from tests of such design. It is a very long way from this type of experiment to the extended series of experiments usually called for in the natural sciences when testing a hypothesis.

These methodological deficiencies in test design entail (if the examples are representative) that one has to question one of the most central assertions of cognitivist scientists of religion: that they work according to the demands and rules of the natural sciences. This problem probably accounts for the self-criticism offered by Armin Geertz $(2004,348)$, when in an introductory article he states that 'much is still hypothetical and in some cases highly speculative' in the cognitive study of religion. One can only agree, and wish that researchers who study 'religion' by means of that discipline's hypotheses were more cautious in their empirical analyses and hypothesis testing and less confident in their conclusions.

Cognitivist scientists of religion have extensively criticised other theoretical perspectives on religion for not having been subjected to empirical testing (as if every theoretical approach were testable according to the laws of the natural sciences), but it is becoming increasingly embarrassing that researchers working within the framework of the cognitive science of religion (where theories are regarded as scientifically testable) have failed 
to produce more than a modicum of cross-cultural empirical evidence for their own hypotheses, despite many attempts to do so. ${ }^{35}$

Why is this still the case? Would it not be possible for a group of researchers with different theoretical points of departure to subject, say, five or ten of the most important hypotheses within the cognitive science of religion to more rigorous testing? It would require breaking down the hypotheses into elements that could be examined by means of carefully formulated questions ${ }^{36}$ which would need to be translated into some fifty different languages and implemented in interviews in fifty or more different cultural settings. By passing on the results of the tests for each hypothesis to a number of researchers for independent evaluation, a substantial body of material would be acquired for further discussion. How, for instance, would Atran, McCauley or Pyysiäinen evaluate tests of Bulbulia's hypothesis of intuitive theism? How would Bulbulia, Geertz or Guthrie evaluate tests of Boyer's hypothesis of minimal counterintuitivity? Or, how would theoretically interested researchers not working within the framework of the cognitive science of religion evaluate the tests? If it is not possible to design such crosscultural tests of the main hypotheses, might it not be because the whole idea of a local semantic category ('religion') that constitutes a universal human attribute is erroneous?

\section{The Problem with the Use of a Western Folk Category in the Analysis of 'Mind'}

Most students of religion would, I think, agree with the point that I have repeated several times, that 'religion' is a western folk category; one which can be used as a heuristic and analytical tool to help us pose hopefully interesting questions with regard to various types of source material. To try to attribute this local semantic category to the human mind, common to all human beings, is not only theoretically problematical but also ethically questionable.

If 'religion' were something universal and attributable to certain predispositions of the brain, and not merely a western folk category, what about all those peoples and languages that we view as 'lacking' a special word for the areas of human activity denoted by our word 'religion'? (Of course,

\footnotetext{
${ }^{35}$ One of the arguments used against critics is that the cognitive science of religion is 'a new science' (Martin 2005, 486), as if that would relieve cognitivists who study 'religion' from having to show due care in their hypothesis testing.

${ }^{36}$ Cf. Barrett's (2005) proposal for the testing of Whitehouse's modes of religiosity theory, and Whitehouse's (2005, 226 ff.) comments.
} 
these people do not 'lack' the term; they do not need it!) Is this western category more real (in some sense) than other categories? How should one regard other ways of structuring reality, ways that do not use the word and category 'religion'?

To my mind, this is one of the most serious theoretical problems with the cognitive science of religion. In addition, it amounts to a new form of western intellectual imperialism. For the analysis of human endeavour and creativity in all its various forms, there is no 'natural category of religion' one can use. In order to analyse other cultures, it is of course necessary to compare indigenous categories with our own; but that is something very different from using any of our own categories as if they were natural (in the sense of 'not cultural') and universal. To regard our categories as a natural point of departure for cultural analysis involves a type of language that other peoples have already heard too much of from western researchers.

Incidentally, one might rhetorically ask in this connection why there is no discussion of whether there might be a cognitive science of dharma or a cognitive science of $d \hat{\imath} n,^{37}$ to mention just two examples of non-western concepts that overlap partly - but only partly - with our notion of 'religion'. Perhaps the problem is best captured in the question posed by S. N. Balagangadhara $(1994,254)$, in his valid objection to the use of 'religion' as a cross-cultural category - with what in this connection is an unintended irony: 'Why is it so counterintuitive for people in the West to believe that there are cultures that do not know of religion?'

\section{Practicability?}

Thus far, I have pointed out a series of problems (at different levels of abstraction) attaching to the cognitive science of religion and the discourses within which it has been formulated. However, I am well aware that I might be wrong or that I might have overstated the problems. But even if we turn a blind eye to the confrontational style and the hegemonic claims; even if we accept pars pro toto arguments, regard minimal counterintuitivity as typical of religiosity, and regard language and religion as close analogues; even if we see no problem in matters of empirical evidence and the testing of hypotheses and do not think it unnatural to take a local folk category as the point of departure for the analysis of the human mind, there still remains the most

${ }^{37}$ Cf. the points of view regarding dharma and dîn in relation to 'religion' in Antes 1994 and Sharma 1994. 
important question to discuss: the problem of practicability. Theories have to be scrutinised as to whether they are logical, coherent, ethical and live up to their own claims; but the most important test of any theory is whether and how it can be used in the analysis of specific research topics.

Suppose we attempted to analyse for instance the different Muslim reactions to the drawings of the Prophet Muhammad in the Danish newspaper Jyllandsposten; the almost explosive growth of Pentecostal movements in some Latin-American countries, but not in others; power and gender in the puberty rituals of girls and boys in present-day Sweden compared to those in Japan; the political force and effects of various Hindu attitudes toward vegetarianism; the social dimensions of calendrical rituals in ancient Assur; or some other topic that most researchers engaged in the non-theological study of religions would find quite legitimate. In application to any of these issues one would probably find the cognitive science of religion to be of little or no help. ${ }^{38}$

If, on the other hand, we wanted to discuss the origins of 'religion' or carry out a comparative analysis of some aspect of 'religious beliefs' worldwide, then one might perhaps use the approaches of the cognitive science of religion as tools. They might help us with certain research questions about 'religion', but there are many questions that per definitionem they could not help us to solve.

As the name makes clear, the cognitive science of religion takes cognition as its point of departure; and since the faculties of the brain and the various cognitive capacities humans have acquired in the history of evolution are common to all human beings, cognitive theories may be of use in analysing themes that have to do with what is common, i.e. similarities. This means that, to the extent they are applicable to religion at all, they can be used to investigate at least two areas of concern. On the one hand, the cognitive science of religion has formulated a series of interrelated hypotheses, albeit sometimes mutually exclusive, that may be helpful in understanding - or explaining - why there is such a thing as religion at all; ${ }^{39}$ although this of course presupposes that one regards religion as an entity of some kind and that this entity is universal. On the other hand - and here it does not matter whether one views religion as an entity or as an analytical concept - these

\footnotetext{
${ }^{38}$ This type of criticism is comparable to that which in the past was aimed at the work of for instance Jean Piaget and Claude Lévi-Strauss. Cf. Sørensen 2005, 487 f. regarding the problem of practicability.

39 As Anttonen (2002) has tried to do.
} 
theories might help us in formulating hypotheses as to how resemblances between religions in culturally unrelated contexts are to be interpreted. However, in both these cases cognitive theories are not the only possible basis on which to build hypotheses but have to compete with other theoretical perspectives. ${ }^{40}$ In other words, cognitive theories might perhaps be used for certain comparative endeavours, but there are also a number of other possible starting points when it comes to the analysis of similarities. And - most importantly - we should remind ourselves that comparison is a matter not just of looking for similarities, but of analysing both similarities and differences.

It is always useful to have a range of theories available when attempting to analyse various things, and it is a good rule to restrict the use of each theoretical perspective to those areas or problems it can address most effectively. The range of a theory is determined by its practical uses in relation to specific research questions. One therefore has to ask: In what way might this theoretical perspective be useful? What type of problems could it help us analyse? And when one asks such questions about the hypotheses formulated within the cognitive science of religion, the answer would be that they might (possibly) help us with themes that focus on 'the typically human', on what is common. If, on the other hand, it is the variations, changes, diversity, complexities, nuances and ambiguities that we regard as making the study of what we call 'religion' so fascinating, we have to resort to other theoretical perspectives to find practicable and heuristic tools to assist us in our analyses.

In the article by Armin Geertz that I have already quoted, the author concludes that 'there is more to cognitive theory than hitherto assumed in the comparative study of religion' (Geertz 2004, 385). I see no reason to disagree, especially since only a few of the perspectives Geertz discusses in his article have so far had any impact within the comparative study of religions, but I think one could also add the opposite point: that there is less to the cognitive science of religion than hitherto assumed by its advocates. It is no wild guess to assume that when the cognitive science of religion reaches maturity and the first enthusiasm begins to cool, it will - like every

\footnotetext{
${ }^{40}$ In this general competition between different theoretical perspectives, those formulated within the cognitive science of religion have so far had limited success. When it comes to the analysis of rituals, for instance, theories formulated from other perspectives, such as those of Bell (1992, 1997), Humphrey \& Laidlaw (1994) or Rappaport (1999), are to the best of my knowledge much more widely applied (i.e. have been found more practicable) than Lawson \& McCauley's approach.
} 
other theoretical approach so far - turn out to be neither as epoch-making as its adherents had hoped, ${ }^{41}$ nor as meaningless and inapplicable as its adversaries had claimed. ${ }^{42}$

\section{Conclusion}

In this article, I have addressed some of the themes I find most problematic about the cognitive science of religion. Needless to say, the study of the evolution of the human brain and its cognitive capacities is an important field of study, and I have had no intention of questioning that field. Problems arise, however, when the epistemological status of the basic concept of a theory is left unresolved; when a theoretical perspective that is good at certain things is presented as though it were the answer to everything; when the results of micro-level investigations of component issues are presented as explanations of the set of issues in its entirety; when problematic concepts and analogies are applied as if they were incontrovertible; when a field of study that claims to belong to the natural sciences does not live up to the strict methodological demands of those sciences; when a western folk category is used as a focal point in the analysis of the human mind, without any discussion of the theoretical - and ethical - dimensions of such a procedure; and when questions about (the limits of) the practicability of a theory are not taken seriously enough.

As I mentioned at the beginning, cognitivist students of religion generally demonstrate a very negative attitude toward all theoretical approaches to religion other than their own. Students of religion working with other approaches have for their part demonstrated much the same negativity towards and lack of interest in the cognitive science of religion. These attitudes probably help to explain why the important discussion about the cognitive science of religion rarely appears in the programmes of seminars and conferences where researchers with different theoretical approaches meet, and is confined instead to debates conducted by more homogeneous groups of participants.

This situation is problematic for all students of religion: an open-minded and critical debate is necessary for the development of any type of intellectual endeavour. The purpose of this paper has been to initiate such a

\footnotetext{
${ }^{41}$ As when Barrett $(2002,107)$ presents it as one of the 'great scientific theories'.

${ }^{42}$ As when Levine $(1998,78)$ presents Lawson and McCauley's method as 'useless' and their conclusions as 'trivial'.
} 
debate. It will have accomplished its task if it contributes in some way to a more open-minded intellectual climate in the theoretical borderland where the cognitive science of religion challenges established academic truths. It is no accident that the incessant and inspiring struggle with theory forms an indispensable part of the life of any scholar or scientist. In that struggle, the cognitive science of religion - even if still controversial - has to be taken seriously enough to be critically discussed, also by those of us who are outsiders.

Bibliography

Alles, Gregory D.

2006 The so-called cognitive optimum and the cost of religious concepts. - Method and Theory in the Study of Religion 18, 325-50.

\section{Andresen, Jensine (ed.)}

2001 Religion in Mind: Cognitive Perspectives on Religious Belief, Ritual, and Experience. Cambridge: Cambridge University Press.

\section{Antes, Peter}

1994 Religion, din et dharma dans la perspective d'une recherche comparative. - Ugo Bianchi (ed.), The Notion of "Religion" in Comparative Research, 763-8. Roma: L'Erma di Bretschneider. (Storia delle Religioni, 8.)

\section{Anttonen, Veikko}

2002 Identifying the generative mechanisms of religion: the issue of origin revisited. - Ilkka Pyysiäinen \& Veikko Anttonen (eds), Current Approaches in the Cognitive Science of Religion, 14-37. London: Continuum.

\section{Asad, Talal}

1993 Genealogies of Religion: Discipline and Reasons of Power in Christianity and Islam. Baltimore: The Johns Hopkins Press.

\section{Ashcraft, Mark H.}

2006 (2002) Cognition. Upper Saddle River, N. J.: Pearson Education.

\section{Atran, Scott \\ 2002 In Gods We Trust: The Evolutionary Landscape of Religion. New York: Oxford University Press.}

Balagangadhara, S. N.

1994 'The Heathen in His Blindness...': Asia, the West and the Dynamic of Religion. Leiden: E. J. Brill. (Studies in the History of Religions, 64.) 
Barrett, Justin L.

2006 (2000) Exploring the natural foundations of religion. - D. Jason Slone (ed.), Religion and Cognition: A Reader, 86-98. London: Equinox. (Critical Categories in the Study of Religion.)

2002 Dumb gods, petitionary prayer and the cognitive science of religion. - Ilkka Pyysiäinen \& Veikko Anttonen (eds), Current Approaches in the Cognitive Science of Religion, 93-109. London: Continuum.

2004a The naturalness of religious concepts: an emerging cognitive science of religion. - Peter Antes \& Armin W. Geertz \& Randi R. Warne (eds), New Approaches to the Study of Religion. 2. Textual, Comparative, Sociological, and Cognitive Approaches (Religion and Reason 43), 401-18. Berlin: Walter de Gruyter.

2004b Why Would Anyone Believe in God? Walnut Creek, CA: AltaMira Press. (Cognitive Science of Religion Series.)

2005 In the empirical mode: evidence needed for the modes of religiosity theory. - Harvey Whitehouse \& Robert N. McCauley (eds), Mind and Religion: Psychological and Cognitive Foundations of Religiosity, 109-26. Walnut Creek, CA: AltaMira Press. (Cognitive Science of Religion Series.)

Barrett, Justin L. \& Frank C. Keil

2006 (1996) Conceptualizing a nonnatural entity: anthropomorphism in God concepts. - D. Jason Slone (ed.), Religion and Cognition: A Reader, 116-48. London: Equinox. (Critical Categories in the Study of Religion.)

\section{Barrett, Justin L. \& E. Thomas Lawson}

2006 (2001) Ritual intuitions: cognitive contributions to judgments of ritual efficacy. - D. Jason Slone (ed.), Religion and Cognition: A Reader, 215-30. London: Equinox. (Critical Categories in the Study of Religion.)

\section{Barrett, Justin L. \& Melanie A. Nyhof}

2006 (2001) Spreading non-natural concepts: the role of intuitive conceptual structures in memory and transmission in culture. - D. Jason Slone (ed.), Religion and Cognition: A Reader, 149-77. London: Equinox. (Critical Categories in the Study of Religion.)

\section{Bell, Catherine}

1992 Ritual Theory, Ritual Practice. New York: Oxford University Press.

1997 Ritual: Perspectives and Dimensions. New York: Oxford University Press.

\section{Bering, Jesse \& David F. Bjorklund}

2006 (2004) The natural emergence of reasoning about the afterlife as a developmental regularity. - D. Jason Slone (ed.), Religion and Cognition: A Reader, 297-336. London: Equinox. (Critical Categories in the Study of Religion.) 


\section{Boyer, Pascal}

1994 The Naturalness of Religious Ideas: A Cognitive Theory of Religion. Berkeley: University of California Press.

2001 Religion Explained: The Evolutionary Origins of Religious Thought. New York: Basic Books.

2002 Why do gods and spirits matter at all? - Ilkka Pyysiäinen \& Veikko Anttonen (eds), Current Approaches in the Cognitive Science of Religion, 68-92. London: Continuum.

\section{Boyer, Pascal \& Charles Ramble}

2006 (2001) Cognitive templates for religious concepts: cross-cultural evidence for recall of counter-intuitive representations. - D. Jason Slone (ed.), Religion and Cognition: A Reader, 178-214. London: Equinox. (Critical Categories in the Study of Religion.)

\section{Bulbulia, Joseph}

2004 The cognitive and evolutionary psychology of religion. - Biology and Philosophy 19, 655-86.

2005 Are there any religions?: an evolutionary exploration. - Method and Theory in the Study of Religion 17, 71-100.

\section{Cerulo, Karen A. (ed.)}

2002 Culture in Mind: Toward a Sociology of Culture and Cognition. New York: Routledge.

\section{Dubuisson, Daniel}

1998 L'Occident et la religion: mythes, science et idéologie. Bruxelles: Éditions Complexe. (Les Dieux dans la Cité: Religions et Sociétés.)

\section{Evans, E. Margaret}

2006 (2001) Cognitive and Contextual Factors in the Emergence of Diverse Belief Systems: Creation versus Evolution. - D. Jason Slone (ed.), Religion and Cognition: A Reader, 231-84. London: Equinox. (Critical Categories in the Study of Religion.)

\section{Fitzgerald, Timothy}

2000 The Ideology of Religious Studies. New York: Oxford University Press.

\section{Flood, Gavin}

1999 Beyond Phenomenology: Rethinking the Study of Religion. London: Cassell.

\section{Geertz, Armin W.}

2004 Cognitive approaches to the study of religion. - Peter Antes \& Armin W. Geertz \& Randi R. Warne (eds), New Approaches to the Study of Religion. 2. Textual, Comparative, Sociological, and Cognitive Approaches (Religion and Reason 43), 347-99. Berlin: Walter de Gruyter. 
Gothóni, René (ed.)

2005 How to do Comparative Religion? Three Ways, Many Goals. Berlin: de Gruyter. (Religion and Reason, 44.)

\section{Guthrie, Stewart Elliot}

1980 A cognitive theory of religion. - Current Anthropology 21, 181-203.

1993 Faces in the Clouds: A New Theory of Religion. New York: Oxford University Press.

2002 Animal animism: evolutionary roots of religious cognition. - Ilkka Pyysiäinen \& Veikko Anttonen (eds), Current Approaches in the Cognitive Science of Religion, 38-67. London: Continuum.

\section{Humphrey, Caroline \& James Laidlaw}

1994 The Archetypal Actions of Ritual: A Theory of Ritual Illustrated by the Jain Rite of Worship. Oxford: Clarendon Press. (Oxford Studies in Social and Cultural Anthropology.)

Jensen, Jeppe Sinding

2002 The complex worlds of religion: connecting cultural and cognitive analysis. - Ilkka Pyysiäinen \& Veikko Anttonen (eds), Current Approaches in the Cognitive Science of Religion, 203-28. London: Continuum.

2003 The Study of Religion in a New Key: Theoretical and Philosophical Soundings in the Comparative and General Study of Religion. Ârhus: Aarhus University Press.

Knight, Nicola \& Paulo Suosa \& Justin L. Barrett \& Scott Atran

2006 (2004) Children's attributions of beliefs to humans and God: crosscultural evidence. - D. Jason Slone (ed.), Religion and Cognition: A Reader, 285-96. London: Equinox. (Critical Categories in the Study of Religion.)

Kolak, Daniel \& William Hirstein \& Peter Mandik \& Jonathan Waskan

2006 Cognitive Science: An Introduction to Mind and Brain. New York: Routledge.

\section{Kövecses, Zoltán}

2006 Language, Mind, and Culture: A Practical Introduction. Oxford: Oxford University Press.

\section{Lakoff, George}

1987 Women, Fire, and Dangerous Things: What Categories Reveal About the Mind. Chicago: The University of Chicago Press.

\section{Lakoff, George \& Mark Johnson}

1980 Metaphors We Live By. Chicago: The University of Chicago Press.

\section{Lawson, E. Thomas}

2000 Towards a cognitive science of religion. - Numen 47, 338-349. 
2004 The relevance of cognitive science for the history of religions. - Birgitte Luchesi \& Kocku von Stuckrad (eds), Religion im kulturellen Diskurs: Festschrift für Hans G. Kippenberg zu seinem 65. Geburtstag / Religion in Cultural Discourse: Essays in Honor of Hans G. Kippenberg on the Occasion of His 65th Birthday, 105-14. Berlin: Walter de Gruyter. (Religionsgeschichtliche Versuche und Vorarbeiten, 52.)

\section{Lawson, E. Thomas \& Robert N. McCauley}

1990 Rethinking Religion: Connecting Cognition and Culture. Cambridge: Cambridge University Press.

Levine, Michael P.

1998 A cognitive approach to ritual: new method or no method at all? - Method and Theory in the Study of Religion 10, 30-60, 78.

\section{Lévi-Strauss, Claude}

1996 (1962) Le totémisme aujourd'hui. Paris: Presses Universitaires de France. (Mythes et religions, 42.)

\section{Lincoln, Bruce}

2003 Holy Terrors: Thinking about Religion after September 11. Chicago: The University of Chicago Press.

\section{Manicas, Peter T.}

2006 A Realist Philosophy of Social Science: Explanation and Understanding. Cambridge: Cambridge University Press.

\section{Martin, Luther $\mathbf{H}$.}

2005 Religion and cognition. - John Russell Hinnells (ed.), The Routledge Companion to the Study of Religion, 473-88. London: Routledge.

\section{Masuzawa, Tomoko}

2005 The Invention of World Religions. Or, How European Universalism Was Preserved in the Language of Pluralism. Chicago: The University of Chicago Press.

\section{McCauley, Robert N. \& E. Thomas Lawson}

2002 Bringing Ritual to Mind: Psychological Foundations of Cultural Forms. Cambridge: Cambridge University Press.

\section{McCutcheon, Russell T.}

2003 The Discipline of Religion: Structure, Meaning, Rhetoric. London: Routledge.

McGuire, Meredith B.

1992 (1981) Religion: The Social Context. Belmont, CA: Wadsworth. 


\section{Pyysiäinen, Ilkka}

2001 How Religion Works: Towards a New Cognitive Science of Religion. Leiden: Brill. (Cognition and Culture Book Series, 1.)

2002 Religion and the counter-intuitive. - Ilkka Pyysiäinen \& Veikko Anttonen (eds), Current Approaches in the Cognitive Science of Religion, 110-32. London: Continuum.

2004 Magic, Miracles, and Religion: A Scientist's Perspective. Walnut Creek, CA: AltaMira Press. (Cognitive Science of Religion Series.)

Pyysiäinen, Ilkka \& Veikko Anttonen (eds)

2002 Current Approaches in the Cognitive Science of Religion. London: Continuum.

Pyysiäinen, Ilkka \& Marjaana Lindeman \& Timo Honkela

2003 Counterintuitiveness as the hallmark of religiosity. - Religion 33, $341-55$.

Rappaport, Roy A.

1999 Ritual and Religion in the Making of Humanity. Cambridge: Cambridge University Press. (Cambridge Studies in Social and Cultural Anthropology.)

\section{Reisberg, Daniel}

2006 (1997) Cognition: Exploring the Science of Mind. New York: W. W. Norton \& Company.

\section{Richert, Rebekah A.}

2006 Modes of research: combining cognitive psychology and anthropology through Whitehouse's modes of religiosity. - D. Jason Slone (ed.), Religion and Cognition: A Reader, 337-51. London: Equinox. (Critical Categories in the Study of Religion.)

\section{Sharma, Arvind}

1994 The bearing of the different understandings of the words religion, dharma, din on religious study and research. - Ugo Bianchi (ed.), The Notion of "Religion" in Comparative Research, 591-602. Roma: L'Erma di Bretschneider. (Storia delle Religioni, 8.)

\section{Sjöblom, Tom}

2007 Spandrels, gazelles and flying buttresses: religion as adaptation or as by-product. - Journal of Cognition and Culture 7, 293-312.

\section{Slone, D. Jason}

2004 Theological Incorrectness: Why People Believe What They Shouldn't. New York: Oxford University Press.

2006a (ed.) Religion and Cognition: A Reader. London: Equinox. (Critical Categories in the Study of Religion.)

2006b Religion and cognition: an introduction. - D. Jason Slone (ed.), Religion and Cognition: A Reader, 1-10. London: Equinox. (Critical Categories in the Study of Religion.) 


\section{Smart, Ninian}

1983 (1969) The Religious Experience of Mankind. Glasgow: Collins.

\section{Smith, Jonathan Z.}

1982 Imagining Religion: From Babylon to Jonestown. Chicago: University of Chicago Press.

\section{Sørensen, Jesper}

2005 Religion in mind: a review article of the cognitive science of religion. - Numen 52, 465-94.

\section{Whitehouse, Harvey}

2000 Arguments and Icons: Divergent Modes of Religiosity. Oxford: Oxford University Press.

2002 Implicit and explicit knowledge in the domain of ritual. - Ilkka Pyysiäinen \& Veikko Anttonen (eds), Current Approaches in the Cognitive Science of Religion, 133-52. London: Continuum.

2004 Modes of Religiosity: A Cognitive Theory of Religious Transmission. Walnut Creek, CA: AltaMira Press. (Cognitive Science of Religion Series.)

2005 Cognitive foundations of religiosity. - Harvey Whitehouse \& Robert N. McCauley (eds), Mind and Religion: Psychological and Cognitive Foundations of Religiosity, 207-s32. Walnut Creek, CA: AltaMira Press. (Cognitive Science of Religion Series.)

\section{Whitehouse, Harvey \& Luther H. Martin (eds)}

2004 Theorizing Religions Past: Archaeology, History, and Cognition. Walnut Creek, CA: AltaMira Press. (Cognitive Science of Religion Series.)

\section{Whitehouse, Harvey \& Robert N. McCauley (eds)}

2005 Mind and Religion: Psychological and Cognitive Foundations of Religiosity. Walnut Creek, CA: AltaMira Press. (Cognitive Science of Religion Series.)

\section{Wright, Georg Henrik von}

1993 (1971) Explanation and Understanding. Ithaca, NY: Cornell University Press. (Contemporary Philosophy.) 
